\title{
Batik industrydevelopment based on rural economic development: the case study of Gunungkidul Regency
}

\author{
Lilies Setiyartiti and Dessy Rachmawatie* \\ Department of Economics, Faculty of Economics and Business, Universitas Muhammadiyah \\ Yogyakarta, Indonesia
}

\begin{abstract}
The purpose of this research is to examine the strategic planning for the development of Batik industrial center based on rural economic development using natural dyes at Gunungkidul Regency. Villages in Gunungkidul Regency have agricultural potential to be developed, one of which is the use of natural dyes as the main ingredient for batik dyes developed in Gunungkidul Regency. Those functions as natural dyes, also functions to maintain environmental ecosystems. Besides playing a role as a source of economic effort for the village community in Gunungkidul Regency, batik crafts have long been part of the traditions of the local village community. Currently, there are 11 sub-districts that are developing batik in Gunungkidul Regency, including the Batik industrial centers in Kepek Village, Petir Village, and Tancep Village. The development of a batik industrial center based on economic empowerment of rural communities in Gunungkidul encourages the improvement of the welfare of the local village community and makes the economy of the village community in Gunungkidul Regency more developed with the presence of a batik center, a batik center which is now being developed as a tourist village in Gunungkidul Regency based on rural economic development.
\end{abstract}

\section{Introduction}

This article aims to examine the strategic planning of developing a batik industry center based on rural economic development using natural dyes in Gunungkidul Regency through a SWOT analysis approach. The batik industry in Gunungkidul Regency is a creative industry dominated by small and medium-sized businesses with considerable potential both regionally and nationally. The batik industry in Gunungkidul Regency has increased after the recognition from UNESCO that batik is an intangible world cultural heritage originating from Indonesia[1].

Through the relevant agencies, the local government is trying to grow and develop batik SMEs in batik centers scattered in the Gunungkidul Regency. Gunungkidul Regency is also trying to support the development of batik centers, especially in Ngawen and Gedangsari Districts which have superior products of natural dye batik. This is stated in the

\footnotetext{
* Corresponding author: d.rachmawatie@umy.ac.id
} 
Gunungkidul Regent's Decree No. 182/KPTS/2016 on the Establishment of Industrial/Craft Centers in the Gunungkidul Regency. where there are 71 industrial centers with 3 (three) of them being batik cloth industrial centers, namely in Padukuhan Sumberan and Padukuhan Sendangrejo, Tancep, Ngawen Gunungkidul. and Hamlet Trembono, Tegalrejo, Gedangsari, Gunungkidul Regency [2].

The application of local motifs as batik motifs is one of the development strategies carried out. The batik industry produces 3 (three) batik products in Gunungkidul Regency, namely, Batik Tulis, Batik Cap, and combination batik [1]. The process of making these three batiks is different. In its heyday, batik artisans only made batik using natural dyes such as teak, noni tree, soga, indigo[3]. They are called batik because of the process of drawing the motif by hand. Making written batik takes weeks and even months if the motif design is complex, so the selling price is also relatively high. The production process of hand-drawn batik is highly dependent on the complexity of the manufacturing process because the level of difficulty of artistry or the length of work determines the price of batik. So that the production of written batik is often only produced to order. One written batik cloth can be valued at 200 thousand rupiahs to millions of rupiahs [4].

Gunungkidul batik, like batik produced by other regions, is currently faced with various challenges of globalization. Challenges grow to be increasingly complex and diverse[5]. Globalization is a fact that cannot be dammed, and this is not a new phenomenon. However, this phenomenon is increasingly felt in the last few decades thanks to the rapid development of technology and communication [2], [5]. The free market in the region and multilateral causes many products, including handicrafts and textiles, to enter the Indonesian market freely[5]. For example, the ASEAN Free Trade Area (AFTA) and the ASEAN Economic Community (AEC) 2015 are now being developed. Indonesia will face many opportunities and challenges ahead of AFTA and AEC. The ASEAN leaders have agreed to transform ASEAN into a free- flow area of goods, services, investment, capital, and labor [2], [5]. AEC describes a globalized economy among ASEAN countries, and $\mathrm{AEC}$ is intended to increase economic competitiveness in the ASEAN region[5].

One of the challenges faced by Gunungkidul batik products is the existence of batik products that come from outside the region, especially from Solo and Pekalongan and imported clothing products that generally have the advantage of being cheaper and of acceptable quality by the local market. High production costs generally cause the low competitiveness of batik products due to the high import content of raw and supporting materials for batik production. In addition, the low productivity of SMEs is due to the low mastery and use of technology. So, the purpose of this study was to examine the strategic planning of the development of batik industry centers based on rural economic development using natural dyes in Gunungkidul Regency through a SWOT analysis approach.

\section{Literature review}

\subsection{Rural economic development}

Rural economic development is a concept of village development to create the welfare of rural communities with the ability to utilize natural resources to meet the production of goods and services[6]. The economy in rural areas is often influenced by the variety and culture of rural communities in meeting their daily needs. Village communities tend to use natural resources as a source of livelihood so that it has an impact on village economic development. A village is a collection of people who maintain cultural values, collaboration, and solidarity. If there is community participation, this is the foundation for the village economy to grow. 
Rural economic development is stated in Law Number 6 of 2014 concerning, village development, as defined in Article 78 paragraph (1), aims to increase the welfare of rural communities regarding human life quality, as well as poverty reduction, by meeting fundamental necessities, development of village facilities and infrastructure, development of economic potential local areas, as well as the sustainable use of natural resources and the environment[6]. In essence, village economic development has the principles of togetherness, kinship, and cooperation to realize the mainstreaming of peace and social justice. The village economic development strategy can be seen in the following figure;

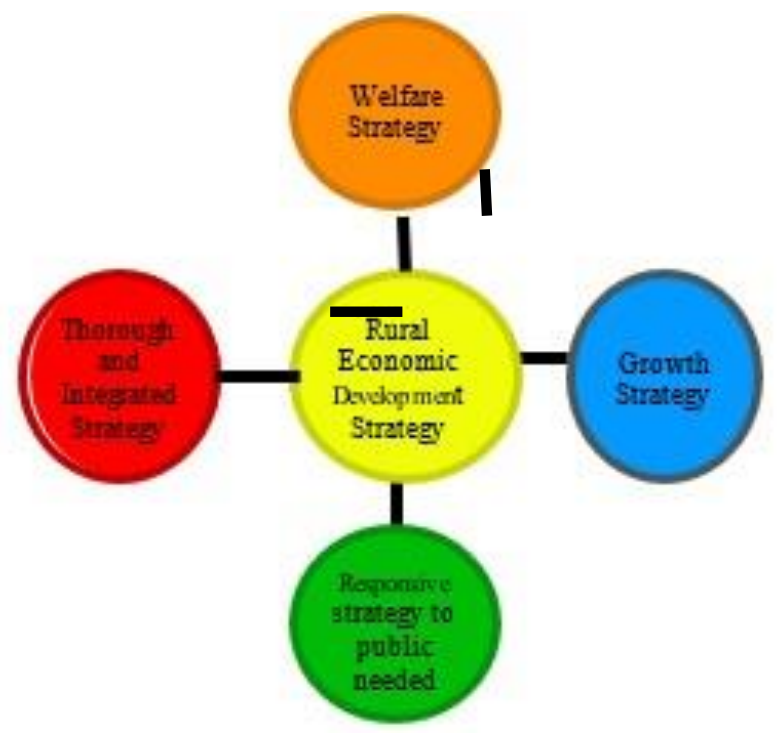

Fig 1. Village economic growth strategy.

The diverse demands of the development of the global environment, the government environment, and the dynamic social environment of society all contribute to rural economic development. As a result, an integrated and comprehensive village development strategy that is sensitive to community needs, together with a growth and welfare strategy, is required. Rural economic development is one of the efforts to better direct and optimize village development from all perspectives in an integrated and coordinated manner[7], [8]. The ultimate goal of development, namely community welfare, maybe attained successfully. Village development is carried out in cooperation by the village authority and the community, employing local wisdom and natural resources. Thus, there are various success criteria for rural economic development[9]: 1) natural resources; 2) capital accumulation; 3) organization; and 4) technological developments. 5) Workforce division; 6) Production scale; 7) Social factors; 8) human factor; 9) political and administrative factors. So that for village economic development to succeed, there are principles of rural economic development, including Transparency, Participation, Sustainable, which can be enjoyed by the community and can be accounted for (accountability)[8]. So, to create an economically empowered village, the government and the community must have these principles in village economic development.

\subsection{SWOT analysis}

When working on a project or a company initiative, a SWOT analysis is a strategic planning technique for analyzing Strengths, Weaknesses, Opportunities, and Threats 
(SWOT). This analysis involves determining the objectives of the business venture or project by identifying excellent and favorable internal and external factors to achieve these objectives[10]. The theory of SWOT analysis is a theory that is used to plan something. According to [11], SWOT analysis collects identities from various factors systematically to formulate service strategies. This analysis is built on a logic that maximizes possibilities while minimizing dangers and weaknesses.

The SWOT analysis has four strategies, including SO (Strength-Opportunities), WO (Weakness-Opportunities), ST (Strength-Threats), and WT (Weakness-Threats). In the SO strategy, the company focuses on strengths outside the company by synergizing together. In comparison, the WO strategy is a strategy that aims to improve the company's weaknesses by taking advantage of profits outside the company[12]. The ST strategy is carried out by implementing the company's strengths to reduce the impact of external threats[20]. Meanwhile, the WT strategy is a company's defensive strategy to reduce internal weaknesses and avoid external threats.

\section{Methods}

The object of research was conducted at the Batik Industry Center in Gunungkidul Regency, which produces batik cloth as well as those who are engaged in batik cloth as batik cloth tailors, which are spread over 5 (five) sub-districts in Gunungkidul Regency with a total of 97 Small and Micro Entrepreneur's (SME's)[4]. This study uses a mix method approach, which uses primary and secondary data. Primary data was obtained through a survey conducted at the Batik Industry Center, Gunungkidul Regency. Secondary data was obtained from the Department of Industry and Trade of Gunungkidul Regency.

Primary data was obtained using survey method, in-depth interview, and focus group discussion (FGD). The interviews followed a semi structured format with an interview guideline that was constructed beforehand, which consisted of open questions. The interviews focused rather broadly on (dis) incentives and motives of the actors involved with the Batik activities. Masterplan analysis is based on the review and evaluation analysis technique, which is the Batik industries were reviewed and evaluated in order to understand which problems often occur in the region.

The main design of this research is through a questionnaire. The questionnaire was designed to collect information about the strengths, weaknesses, opportunities and threats (SWOT) of batik business actors at the Batik Industry Center in Gunungkidul Regency. Each SWOT element is represented by 10 questions and participants record their responses using a 5-point Likert-scale ( $1=$ Strongly Disagree and 5=Strongly Agree). The number of questions was 40 and the survey was conducted using a questionnaire. Demographic questions were provided at the end of the questionnaire to gather information about the participants. A short open-ended interview was conducted after the participants answered all the questions to gather further information about the potential of the batik industry in Gunungkidul Regency. SWOT analysis is defined as a tool for strategic management for companies to determine internal and external factors. Prior to conducting this survey, questions consisting of elements in SWOT (Strengths, Weaknesses, Opportunities, Threats) were identified based on the literature. The 10 questions from each element were designed to help the researcher analyze the perceptions of the target group.

The analytical method used in this study uses the SWOT analysis method. SWOT analysis is used to identify various factors, both internal and external, which are systematically used to formulate a strategy for developing the Batik Industry Center in Gunungkidul Regency. This analysis is built based on logic that can maximize strengths and opportunities, and at the same time minimize weaknesses and threats[14].

The definition of strength refers to the internal elements of business actors at the Batik 
Industry Center in Gunungkidul Regency that facilitate the achievement of its goals, while weaknesses are internal elements that interfere with the success of business actors at the Batik Industry Center in Gunungkidul Regency[15]. Opportunities are external aspects that help business actors at the Batik Industry Center in Gunungkidul Regency achieve their goals, this is not only in the context of positive environmental aspects but also opportunities to overcome gaps and start new activities. Threats, on the other hand, are aspects of the external environment of business actors at the Batik Industry Center in Gunungkidul Regency which are potential obstacles or obstacles to achieving their goals[16].

The SWOT analysis method is based on the analysis of internal factors (strengths and weaknesses) and external factors (opportunities and threats) at the Batik Industry Center in Gunungkidul Regency. Internal factor analysis is done by making IFAS (Internal Factor Analysis Summary) and EFAS (External Factor Analysis Summary) matrices[15], [16]. After doing the values of the IFAS and EFAS matrices, it can be seen the position of the changes in the values of the IFAS and EFAS matrices on the SWOT analysis diagram.

\section{Finding and discussion}

\subsection{Condition of batik center in Gunungkidul}

There are many home industries that produce batik scattered in various sub-districts in the Gunungkidul Regency area. The following is data on batik IKM based on data from the Disperindag Kab. Gunungkidul In 2018, especially those at the location of the preparation of the master plan for the development of batik centers in 6 sub-districts:

Table 1. Batik SMI data at the Batik Center Kab. Gunungkidul In 2018.

\begin{tabular}{|c|c|c|c|c|}
\hline Subdistrict & Villages & Hamlet & $\begin{array}{c}\text { Number of } \\
\text { SMEs }\end{array}$ & SME Category \\
\hline Gedangsari & Tegalrejo & Trembono & 3 & $\begin{array}{l}\text { Manufacturer of batik } \\
\text { cloth }\end{array}$ \\
\hline Ngawen & Tancep & Sendangrejo & 20 & $\begin{array}{l}\text { Manufacturer of batik } \\
\text { cloth }\end{array}$ \\
\hline Ngawen & Tancep & Sumberan & 36 & $\begin{array}{l}\text { Manufacturer of batik } \\
\text { cloth }\end{array}$ \\
\hline Playen & Ivory & Ivory 1 & 2 & $\begin{array}{c}\text { Batik fabric tailor and } \\
\text { batik producer }\end{array}$ \\
\hline Playen & Logandeng & Glidag & 1 & $\begin{array}{c}\text { Batik fabric tailor and } \\
\text { batik producer }\end{array}$ \\
\hline Playen & Logandeng & $\begin{array}{l}\text { Siyono } \\
\text { Wetan }\end{array}$ & 1 & $\begin{array}{c}\text { Batik fabric tailor and } \\
\text { batik producer }\end{array}$ \\
\hline Wonosari & Kepek & Bansari & 33 & $\begin{array}{l}\text { Manufacturer of batik } \\
\text { cloth }\end{array}$ \\
\hline Saptosari & Kepek & Gondang & 1 & $\begin{array}{l}\text { Manufacturer of batik } \\
\text { cloth }\end{array}$ \\
\hline \multicolumn{3}{|c|}{ Total } & 97 & $\begin{array}{l}\text { Manufacturer of batik } \\
\text { cloth }\end{array}$ \\
\hline
\end{tabular}

Source : [13]

\subsubsection{Batik industry center in Trembono, Tegalrejo Village, Gedangsari Sub-district}

Gedangsari sub-district has significantly developed batik, and the batik makers have been 
certified by the DIY Manpower Office. In addition, Gedangsari District already has a unique batik motif that has been patented, namely the Buron Wono motif for being the winner of the Gunungkidul Typical Batik Motif Design Competition in 2011. Tegalrejo Village, especially in Trembono Hamlet, is one of the areas that has a batik center in Gunungkidul[4]. Therefore, the local village government continues to focus on developing its batik natural colored. Thanks to the creations of these hundreds of artisans, batik from Tegalrejo is widely known. But the proudest thing is that this creation has its motive. The batik motifs owned include Ratuning Gedangsari I, Ratuning Gedangsari II, Pring Sedapur and Sekaring Gedangsari.
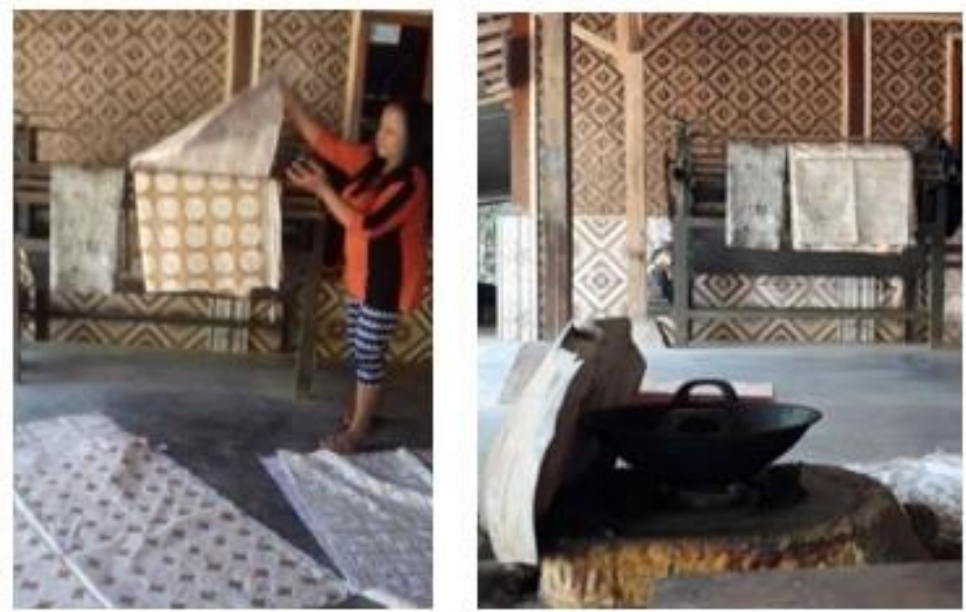

Fig. 2. Batik Center in Trembono Hamlet, Ds. Tegalrejo, Gedangsari District.

Tegalrejo village is located about $45 \mathrm{~km}$ north of the central government of Gunungkidul Regency, and it does have quite a lot of residents who work as batik. Road access to the location of the terrain is quite tricky because it is hilly and lacks markers such as gates, signposts, and placards with the name of the location. There you can see the batik activity of several artisans.
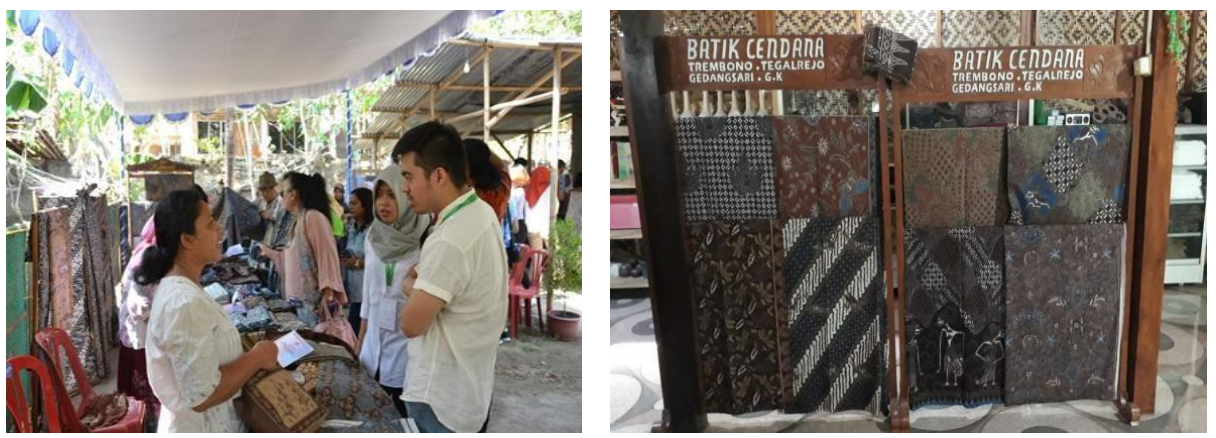

Fig.3. Hand-drawn Batik with Natural Colors and Expo at the JIBB event.

The price of written batik is sold at various prices, starting from IDR 250,000.00 to IDR $500,000.00$ and can even reach a price of more than IDR 1,000,000.00 per sheet. The high selling value, of course, cannot be separated from the long process of making batik and the uniqueness of Gedangsari batik itself, one of which is in terms of coloring. The Gedangsari batik coloring process uses natural dyes. The dyes are processed from natural resources 
around them, such as teak tree leaves and bark, mangosteen peel, mahogany wood, Putri Malu leaves, Indigofera leaves, mango leaves, and Jalawe leaves. Besides the color looks more beautiful and durable, the use of these dyes also makes Gedangsari batik more environmentally friendly. The wider community has known Tegalrejo Gedangsari Batik. And it was once one of the Heritage Tour destinations for the Jogja International Batik Biennale (JIBB) in October 2018[5]. But so far, batik products from Trembono Padukuhan have only reached marketing areas around DIY, especially Kab. Gunungkidul or even further depending on the location of the exhibition event.

\subsubsection{Tancep Village, Ngawen Sub-District}

Batik Tancep is taken from the name of a village in Ngawen District, namely Tancep Village. Judging from its history, it comes from two different hamlet areas, namely Sumberan and Sendangrejo hamlets. Batik Tulis Tancep has a unique market share and can compete with batik from outside the region. Batik Tulis Tancep is unique for batik lovers, namely batik dyes derived from natural and environmentally friendly materials. The dyes used are found in their environments, such as acacia, mahogany leaves, Tanjung, and many natural dyes are used.

Batik Motif Tancep is produced by order. There are 12 (twelve) types of written batik with various forms of motifs, including Angrem Baboon motifs, Bokor Mas, Birowo Elephant, Sekar Jagad, Ganggeng, Prahu Lines, Sekar Kanthil, Temples, and Revelation. Batik Tancep or known as Batik Tulis Tancep is a batik craft produced by batik craftsmen in Gunungkidul. Babon Angrem motif is a picture of a hen incubating her eggs, interpreted as a pregnant mother should have a sense of patience and love so that later the child, she is carrying will inherit these traits. Meanwhile, the Jejeran Prahu motif depicts a row of neatly lined boats that symbolize a life that goes hand in hand and rhythmically according to the people of Gunungkidul living a life full of meaning and goes hand in hand amid existing differences.

The making of Tancep Batik is classified as traditional, namely by manually making motifs and coloring with natural materials. The marketing of Tancep Batik is still following the surrounding batik markets, namely Yogyakarta and Solo, because not many buyers have come directly to the location or manufacturing center[2]. Batik Tancep Ngawen has a slightly different motif and color from the types of batik that have been known for a long time, namely the typical Jogja batik and the Solo batik. The two types of batik are a comparison because the location of Ngawen itself is in the middle between Yogyakarta and Solo. Batik Tancep Ngawen is that many batiks are produced in purplish-blue, green, and brown colors. Although it has different motifs and colors from Jogja Batik and Solo Batik, in practice, Batik Tancep Ngawen is still influenced by both. This is because Batik Tancep Ngawen has a market share in Jogja and Solo.

\subsubsection{Gading I Hamlet, Gading Village, Playen District}

In Hamlet Gading I, there is a batik production house called Batik Manggar Gading, which has approximately ten batik craftsmen. The access road to the location is relatively easy because it is on the edge of the main road and is in the middle of the city, and there is already a marker in the form of a location name plaque. This batik house produces stamped and written batik with natural and synthetic dyes. For new marketing around DIY, especially Kab. Gunungkidul. 

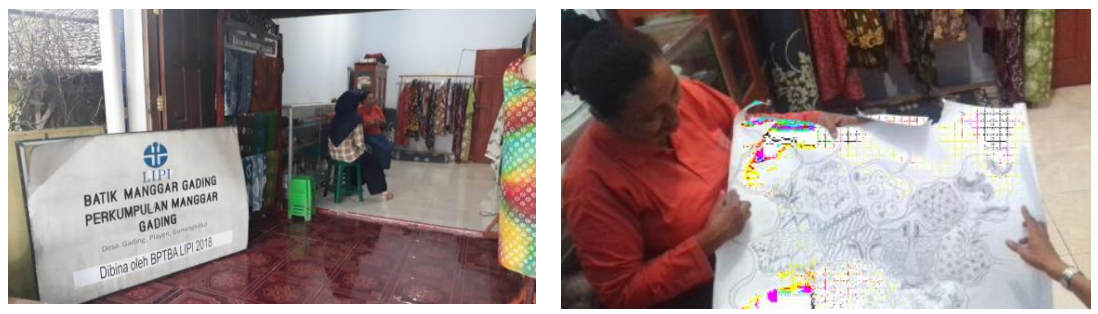

Fig. 4. Batik Center in Hamlet of Gading I, Gading Village, Playen District.

The batik motif developed is the Manggar motif based on the uniqueness of the Gading Village area, which has many flowering coconut trees (Manggar). But unfortunately, there is no Waste Treatment Plant (IPAL) in this batik village, so the waste is only dumped into a big enough hole made in the middle of their yard/garden, [3] then backfilled with soil when enough waste has been wasted disposed of. After that, it will move to make another hole that is still in the yard. So far, there has been no impact on the craftsmen or residents, but they hope to receive socialization and facilitation in managing the waste they produce.

\subsubsection{Glidag Hamlet, Logandeng Village, Playen District}

In Glidag Hamlet, Logandeng Village, one house is a group of tailors named Omah Melati who developed the manufacture of batik clothes from local motifs, which at first did not produce batik cloth[1]. But now, little by little, they began to learn and produce their batik cloth. The location is relatively easy to reach because it has registered its business location on Google Maps even though it is located with minimal markers such as gates, road signs, or location name placards.

In Omah Melati, five craftsmen specialize in producing batik. They buy batik raw materials such as Mori cloth, canting, Malam, and synthetic dyes from Yogyakarta. The batik produced includes written batik and Jumputan batik, but most of them still use synthetic dyes[17]. This is because they have not been able to process natural dyes into ready-to-use dyes that are durable when applied to Mori cloth. If there is an order for written batik with natural dyes, they will design and then color it at the batik center in Tancep, Ngawen District. They hope that there will be training in coloring batik with natural dyes. The wastes that arise from batik production activities are only disposed of on the ground they excavated and then backfilled and then reused like that repeatedly.

However, they are still enthusiastic about developing batik motifs in the production house by making several mainstay motifs, including the Sumatran Melati motif, Godong Jati Peacock, Walang Strawberry, and so on, which are inspired by the environmental conditions around them. The price range offered for written batik is between IDR 200,000.00 - IDR 600,000.00. For jumputan batik, it costs IDR 150,000 - IDR 200,000.00, while batik jumputan for written combination is IDR 250,000.00. Batik products from Omah Melati have been mar- keted through online social media to reach Jakarta, Semarang, Kalimantan, Sulawesi, and even Papua. However, the amount is still fluctuating to only sell eight pieces per month on average. 

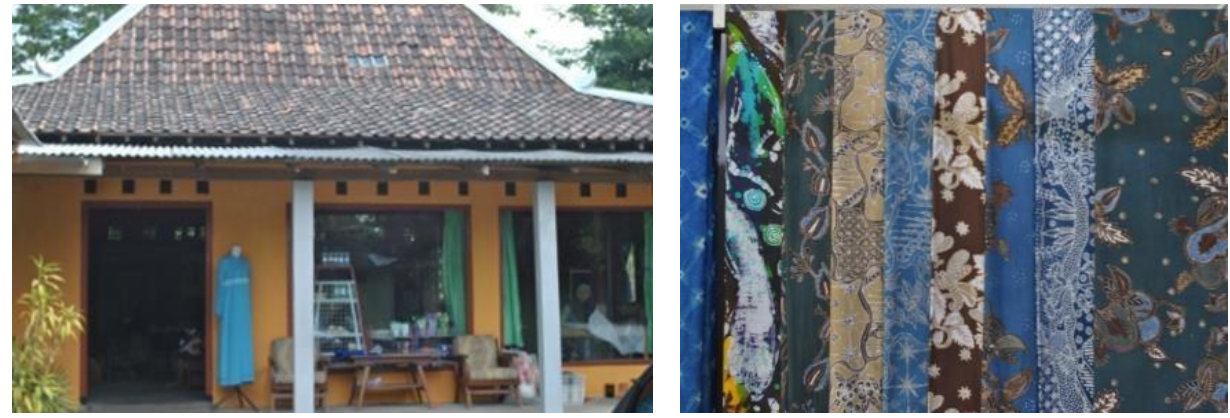

Fig. 5. Batik Center in Glidag Hamlet, Logandeng Village, Playen District.

The batik industry in Gunungkidul Regency is small and medium. The fact is that at this time, Indonesia has been flooded with batik products originating from China with prices that are much cheaper and quite diverse[2]. Batik produced by Indonesia is better in terms of quality, but the price is still relatively higher than products from China[2]. This is a challenge for Gunungkidul batik entrepreneurs to increase the competitiveness of their batik industry. Although batik results from the creation of the nation's children who are thick with culture, it is not easy to promote the use of batik based on the quality and value of nationalism. The consumer community is faced with imported batik products that are cheaper with quality below the national product.

\section{a. Availability of batik equipment}

In Indonesia, of the 19 cities that are centers of batik in Indonesia, only six businesses make cantings, 31 businesses that make batik stamps, and ten businesses that make wax mixtures. The total number of batik businesses spread across Java is 15,293 units[5]. Canting is the leading equipment in the batik industry, primarily written batik so that the shortage of canting producing companies will indirectly affect the productivity of the written batik industry. If this continues, the batik industry in Indonesia and Gunungkidul district will be increasingly unable to compete with other textile products or batik products with stamping techniques[17].

The limited number of batik stamp producers will also affect the productivity of stamped batik in Gunungkidul, especially when the demands of high competition require batik artisans to be creative in the pursuit of batik motifs that are by market tastes and have distinctive characteristics. Therefore, orders for batik stamp designs will also be more diverse, and the implication is that orders for batik stamp equipment will take a long time.

\section{b. Price fluctuations of Mori cloth}

The Mori cloth used as a batik medium consists of Primisima Mori and prima Mori, recording a significant price increase due to the increase in cotton prices since 2009[2]. Whereas for written batik, the average craftsman uses Primisima Mori cloth because Prisimisa Mori is also smoother and does not get dull quickly for batik in addition to its good quality. If the price of these raw materials tends to rise continuously, then the production cost for each piece of written batik cloth will be more expensive. Finally, artisans are reluctant to produce batik, except only by order.

\section{c. Batik entrepreneur management skills}

Limited human resources are also one of the severe obstacles for SMEs in Indonesia, 
especially in the aspects of entrepreneurship, management, production engineering, product development, quality control, accounting, machinery, organization, data processing, marketing techniques, and market research[4]. All these skills are needed to maintain or improve product quality, increase efficiency and productivity in production, expand market share and penetrate new markets.

\section{d. Regeneration}

The progress and development of batik in Gunungkidul Regency are not matched by batik's regeneration, primarily written batik art. The lack of regeneration makes the number of batik artisans less and less and is only dominated by the elderly. Batik art is a people's economic activity with a strategic position, potential, and role to realize the structure of the national economy. Most of the existing batik centers in Gunungkidul Regency are old or old. Some are even 85 years old who still make batik [17]. Unfortunately, the younger generation doesn't like this field. After graduating from SMK or SMA, the youth mostly choose to work in other sectors, such as becoming salespeople or employees in private companies. If no effort is made to regenerate the batik sector, then in the not-too-distant future, batik will become increasingly inflamed in increasingly fierce competition.

\section{e. Capital or financial aspects}

Because small industries dominate most batik artisans, financial problems are essential because access to funds from formal financial institutions such as banks is not easily accessible. After all, many batik business actors are unable to meet pretty heavy bank requirements. This condition causes batik artisans to face two main financial aspects: capital (both initial and working capital) and long-term finance for investment, which is needed for long-term output growth.

\subsection{Results of the SWOT analysis of the Batik industry center of Gunungkidul}

The handicraft and batik industry are one type of industry in the creative industry sector. Before the monetary crisis in 1997, this small and medium industry had experienced rapid progress. Some batik entrepreneurs had experienced a heyday. Moreover, in the 1980s, batik was an official attire that had to be worn at every state event or other official event. So that it can introduce and improve the image of batik in the international world at that time. The batik industry in Indonesia is spread over several areas on the island of Java which later became the names of these types of batik, such as Pekalongan batik, Surakarta batik, Yogya batik, Lasem batik, Cirebon batik, and Sragen batik. Each batik from the area has a specific motif [2]. There are three types of batik produced, namely written batik, stamped batik, and com- bination batik [4]. The development of the batik industry in Indonesia is closely related to batik development, which began hundreds of years ago. Batik is a type of clothing product that has developed rapidly in Java since several hundred years ago.

The batik industry in Indonesia is generally a small and medium industry (SME), which is the livelihood of some people, and the Gunungkidul Regency area, which has the potential of the batik industry. Most Indonesian people are familiar with batik in both traditional and modern styles. The history of batik in Indonesia is closely related to the development of the Majapahit kingdom and the spread of Islamic teachings in Java. The development of batik was mainly carried out during the Mataram kingdom and then during the Solo and Yogyakarta kingdoms. The spread of the art of batik belongs to the people of Indonesia and the Javanese, especially after the end of the XVIII century or the beginning of the XIX century[5]. At that time, the batik produced was written batik. After World War I or the 1920s, the batik cap was known. So, from its history, it can be seen the development of 
batik which started from the Majapahit era. The area of batik now that can be seen from the Majapahit era is Mojokerto, namely Kwali, Mojosari, Betero and Sidomulyo. Meanwhile, the area of batik originating from the spread of Islam is currently in Ponorogo (roughly stamped batik or blue mori stamped batik. Meanwhile, Solo and Yogyakarta batik perfected the existing batik pat- terns in Mojokerto and Tulung Agung, and also spread to Gresik, Surabaya and Madura, while to the west, batik is developing in Banyumas, Pekalongan, Tegal and Cirebon. Besides that, batik is also known in Jakarta and West Sumatra. But the center of the batik industry is still the island of Java. The area of batik now that can be seen from the Majapahit era is Mojokerto, namely Kwali, Mojosari, Betero and Sidomulyo. Meanwhile, the area of batik originating from the spread of Islam is currently in Ponorogo (roughly stamped batik or blue mori stamped batik. Meanwhile, Solo and Yogyakarta batik perfected the existing batik patterns in Mojokerto and Tulung Agung, and also spread to Gresik, Surabaya and Madura, while to the west, batik is developing in Banyumas, Pekalongan, Tegal and Cirebon. Besides that, batik is also known in Jakarta and West Sumatra. But the center of the batik industry is still the island of Java. The area of batik now that can be seen from the Majapahit era is Mojokerto, [5] namely Kwali, Mojosari, Betero and Sidomulyo. Meanwhile, the area of batik originating from the spread of Islam is currently in Ponorogo (roughly stamped batik or blue mori stamped batik. Meanwhile, Solo and Yogyakarta batik perfected the existing batik pat- terns in Mojokerto and Tulung Agung, and also spread to Gresik, Surabaya and Madura, while to the west, batik is developing in Banyumas, Pekalongan, Tegal and Cirebon. Besides that, batik is also known in Jakarta and West Sumatra. But the center of the batik industry is still the island of Java. In addition, batik is also known in Jakarta and West Sumatra[4]. But the center of the batik industry today is still the island of Java. In addition, batik is also known in Jakarta and West Sumatra. But the center of the batik industry today is still the island of Java.

The batik industry in Gunungkidul today is starting to increase[17]. It is not only used when it is official and is identical to parents. Now batik has also begun to attract young people. Through a touch of design and innovation, batik is now starting to be glimpsed by young people. Even in Gunungkidul, many have been patented. More and more people are devel- oping batik in the Gunungkidul Regency area; even as many as 11 sub-districts have devel- oped batik [2]. Finally, the Batik Village was launched in Kepek, Wonosari. Even the develop- ment of batik has been supported by quite good marketing through the internet. The devel- opment of batik in Gunungkidul will further encourage the improvement of people's welfare and make the economy of Gunungkidul Regency more developed with the existence of a batik center.

The batik industry produces 3 (three) batik products in batik centers in Gunungkidul Regency, namely, written batik, stamped batik, and combination batik. The process of making the three types of batik is different. In its heyday, batik artisans only made batik using natural dyes such as teak, noni tree, soga, indigo[4]. They are called batik because of the process of drawing the motif by hand. Making written batik takes weeks and even months if the motif design is complex, so the selling price is also relatively high. A piece of written batik cloth can be valued at 200 thousand rupiahs to millions of rupiahs[18].

The price and quality of the batik are highly dependent on the complexity of the manufacturing process. The level of difficulty of the work or the duration of the process determines the price of batik. If the production technique for one batik cloth takes time, the price is also different from batik made with the stamp technique[1]. So, this batik production is only produced to order. The second type of batik is stamped batik. It is called stamped batik because the batik motif is formed with a stamp, usually made of copper[2]. Stamped batik is also known as printed batik. So that in its development, a type of screen printing production emerged, namely the use of handprints to print motifs on cloth. With this stamp system's production process, the craftsmen can produce more batik production 
because the manufac- turing process is not too long.

SWOT analysis in this study is applied by analyzing and sorting out various things that affect the four factors, then applying it in a SWOT matrix image, where the application is how strengths can take advantage of existing opportunities, how to overcome weaknesses (weaknesses) that prevent the advantages (advantages) from existing opportunities (opportunities), then how the strengths (strengths) can face the threats (threats) that exist, and finally how to overcome the weaknesses (weaknesses) that can create threats (threats) become real or create a new threat[10], [15]. During times of indecision, a strengths, weaknesses, opportunities, and threats (SWOT) analysis has become a critical tool for firms to evaluate their market position and is frequently used to study the internal and external environments of enterprises [14]-[16].

\subsubsection{Internal factors analysis (IFAS)}

Internal factor analysis, which includes strengths and weaknesses, is carried out to determine the condition of the area internally[11]. Strength is a resource or capability controlled by or available to a company that makes the company relatively superior to its competitors in meeting the customers' needs. While weakness is a limitation or deficiency in one or more resources or capabilities of a company relative to its competitors, which becomes an obstacle in meeting customer needs effectively.

Concerning the development of batik centers in Gunungkidul Regency, in general, they already have a lot of strength, most of which comes from human resources (HR). The human resources in question are those who already have qualified skills in batik and their willingness to continue to struggle in the world of batik and develop it. In addition, the shift in people's tastes towards something environmentally friendly is supported by the existence of resources in the form of natural dyes that can be applied as batik dyes. Therefore, these conditions become reinforcement in supporting the existence of the batik industry with natural dyes.

Unfortunately, there are still some weaknesses in the batik industry in Gunungkidul Regency, including the craftsmen who have not been able to extract natural dyes into readyto-use dyes, so they have to buy from other areas. Likewise, other batik equipments such as cloth, canting, and wax are more often purchased from the city of Yogyakarta or in Solo[19]-[21]. Although using natural dyes, of course, the problem of waste cannot be ruled out. However, they also do not have a Waste Water Treatment Plant (IPAL). In addition, in terms of business finance, most centers experienced difficulties in terms of capital and access to loans to finan- cial institutions.

\subsubsection{External factors analysis (EFAS)}

Analysis of external factors, including opportunities and threats, is carried out to determine the region's position in dealing with its external environment[14]. Opportunities are the central favorable situation in a company's environment, while threats are the main unfavorable situations in a company's environment[15].

Gunungkidul Regency has opportunities that support the development of batik industrial centers with great natural dyes available in the villages of Gunungkidul Regency. In terms of government, the Special Region of Yogyakarta has the Special Law of Yogyakarta, one of which encourages the cultural development of the batik sector. In addition, the existence of regional autonomy provides an opportunity for local governments to develop their regions, especially those related to the development of batik businesses. This is also supported by people of various ages who are interested in natural dyed batik. Moreover, there are also many exhibitions of batik products that are becoming more well known. The 
Yogyakarta area as one of the tourism destinations in Indonesia, both by foreign and domestic tourists, has caused the national and international tourism market to shift from mass tourism to special interest tourism, including batik tourism. By developing a center for the Batik Industry, this effort can encourage the economic development of villages in Gunungkidul Regency.

Currently, in Yogyakarta, especially in Gunungkidul Regency, public awareness of the importance of a healthy and sustainable environment is getting better. The demand for batik with natural coloring is getting higher. In addition, the very positive support from the Regional Government of Gunungkidul Regency for the development of the batik center is also getting better. Policies from both the central government and local governments regarding the obligation to wear batik on certain working days, including school students[2]. Culture has become a leading commodity offered by the government at the provincial and district levels, related to the Special Law of Yogyakarta, including the cultural development of the batik sector. In addition, public interest and the younger generation have started to like batik clothing.

The existence of written batik as a cultural heritage of the Indonesian nation has been recognized by UNESCO as an Indonesian cultural heritage. However, batik has been recognized by other countries as a cultural heritage of other nations. This is something that must be maintained so that it remains a national asset. Then the existence of the AEC (ASEAN Economic Community) makes the market share more wide open for foreign products so that business opportunities are getting tighter. Various textile products, of course, enter and become non-batik competitors for the domestic batik industry, especially in Gunungkidul Regency. Moreover, almost all districts in Indonesia have batik industries with their characteristics, so the competition in the batik clothing business market is becoming increasingly authoritarian.

The AEC (ASEAN Economic Community) existence makes the market share morewide open for foreign products so that business opportunities are getting tighter. Therefore, innovation is needed both in production and post-production[5], [18]. For example, in the face of the Covid-19 pandemic, a marketing engineering model with a digital marketing system is needed, namely by encouraging online market opportunities that can be reached by using information technology through e-commerce. So that the arrival of the Covid-19 pandemic, which has been running for almost 2 (two) years, which can pose a threat to small industry players, with marketing engineering by utilizing information technology, can create potential market opportunities that can reach consumers without limits, not only consumers who are in Yogyakarta,

Another threat is that almost all districts in Indonesia have batik industries with their characteristics. The competition in the batik clothing business market is becoming increasingly authoritarian. Therefore, it is necessary to have innovation in the production process, which is the mainstay of Gunungkidul batik, so that the batik of Gunungkidul Regency has its characteristics and identity with the types of batik that are already widely available in the batik market, such as solo batik, Pekalongan batik, Madura batik, and so on.

\subsection{Development of a Batik industry center based on rural economic development}

The development of batik centers is a series of efforts that see a center as a unified whole of production activities. The programs designed and implemented are adapted to the problems and conditions of the center concerned in a comprehensive and integrated manner. These programs provide and develop various forms of facilities and infrastructure that are calculated to encourage the development of the batik center concerned. In practice, these programs are expected to directly increase the income and standard of living of batik artisans 
and society in general.

Empowerment-oriented programs based on rural community development will ensure sustainability. This program is not solely oriented towards physical-material results but is more process-oriented, primarily through social learning processes. The physical- material presence determines the program's success implemented in a community, but by realizing these results, how far the community has been involved is driven by its determination, awareness, and social responsibility, not by being mobilized[4]. Suppose the implementation of the program requires various forms of joint activities. In that case, the community, through the social learning process, is expected to have the capacity to plan, implement and manage joint activities to improve their living conditions. Thus, the preparation of institutional aspects is essential in the implementation of designing and implementing the program. This institutional program has the main target of developing community competence to improve living conditions and institutionalization of various joint activities.

Institutionalization is not just the presence of institutions in being an organization that accommodates joint activities. What is more important is that these joint activities have become part of the system and community behavior patterns and become part of social institutions. A further impact of this institutionalization is the sustainability of the development process or efforts to improve people's living standards because there is no more extended dependence on external parties[22]. Concerning external parties, the institution will become a kind of two-way communication bridge so that it can adapt programs from external parties to the actual problems and needs of the community and so that the benefits of sharing programs can be spread to all existing levels of society.

Meanwhile, the procurement program and the development of infrastructure and facilities to support the development of batik centers and efforts to increase the income of batik artisans and the community are expected to encourage the socio-economic development of the batik centers concerned. The development of various forms of infrastructure and facilities will connect the relationship between the centers of development of batik centers with markets or consumers. Ideally, the construction of the infrastructure network is expected to produce a synergistic relationship between the production center and the market or consumer. Therefore, it is necessary to maintain that what emerges is the spread effect mechanism.

The development of the Gunungkidul Batik Center uses the approach or concept of "Developing a Competitive and Sustainable Gunungkidul Batik Center" to spur the economic growth of the batik center. The development concept is a development concept by seeing that batik centers have potentials as drivers of regional economic growth. The existence of batik centers in rural areas will also be the energy of economic development in rural areas [8]. If growth is allowed to occur spontaneously and is not planned sustainably, it is feared that rural areas will continue to decrease in the future.

Most rural areas often face a low level of income even though it is rich in potential resources. To achieve a sustainable development program, the scope of development of batik centers is partial but must be interpreted more broadly, namely spatially. Therefore, the concept of Developing a Competitive and Sustainable Gunungkidul Batik Center includes four (4) essential pillars, namely: First, empowering the economy of rural communities through the development of batik centers. In this effort, capital input and guidance on the use of technology and marketing are needed to enable and empower batik business actors; Second, increasing the resources of rural communities so that they have an adequate basis to increase and strengthen the productivity and competitiveness of batik centers; Third, the development of batik center infrastructure to spur the growth of batik centers and rural economic growth to eliminate backwardness; Fourth, build a good batik center institution as a supporter of batik center development. So, it is hoped that the efforts to develop the Batik 
Industry Center in Gunungkidul Regency can encourage income generating growth for rural communities. This is under the research results conducted by Almasdi Syahfaza, namely about the acceleration of the rural economy through the development of oil palm plantations and 15 other relevant journals related to research showing that rural development can improve the community's economy. This is because rural economic development is based on the literature analyzed that rural communities are closely related to mutual collaboration and unity principles. In addition, the characterization of rural communities in their daily lives utilizes natural resources so that in this way, the village economy grows. Village economic development can be achieved with principles that are under the community's needs and aim at the welfare of the rural community.

The concept of Developing a Competitive and Sustainable Gunungkidul Batik Center is offered because the performance of the batik center is not yet optimal but has the potential to develop in the future. On the other hand, the phenomenon of urbanization (migration from villages to cities) increasing every year is feared to make it difficult for regeneration in the batik industry sector. On the other hand, there is also a disparity between urban and rural areas, which is quite large. It needs to be resolved by integrating an integrated batik center development program, based on the regional scope, and is sustainable. Therefore, the aim of developing a competitive and sustainable batik center is through improving the production process, improving product quality and technology, developing access to market information.

\subsubsection{Strategy for development of Batik industry center in Gunungkidul Regency}

Based on the results of the analysis that has been presented previously, it can be formulated a strategy for developing the Batik Industry Center, as follows:

a. Development and optimization of batik centers based on the philosophy and characteristics of each center for both natural and synthetic color batik

a) Empowering batik centers to increase batik production and quality through a system of developing batik motifs and natural coloring

b) Promotion of batik tourism to increase the number of visitors to the batik center, improve the attractiveness of batik tourism to ensure the length of stay of tourists is getting longer.

c) Increase productivity and added value through skill improvement, product modification, and design and strengthen access to market information and access to capital.

d) Development of various batik products to support tourist attractions: batik cloth, finished products, and souvenirs made from batik.

b. Improved accessibility and service coverage of transportation, communication, and infrastructure network infrastructure

a) Develop and provide a network of infrastructure that encourages the formation of a synergistic chain of tourism activities, the economy, and batik production centers.

b) Physical infrastructure development to ensure the integration of the local community's economic, social, and cultural activities.

\section{c. Human resource development and rural community development}

a) Increasing the managerial capacity of batik entrepreneurs and batik craftsmen.

b) Assistance to various groups of batik craftsmen to increase added value to artisans.

c) Development of exceptional interest tourism potential with the theme of batik with 
natural dyes.

d) Intensive guidance and development of Tourism Awareness Groups so that they are more professional so that their involvement is higher in developing batik tourism potential.

e) Encourage community participation to be more dominant as the implementation of the batik center development program. The function of the local government bureaucracy is more of a regulator, facilitator, and stimulator of batik center development.

\section{d. Strengthening financial aspects and access to market information}

a) Encouraging and facilitating batik business actors to be involved in batik exhibitions and expos, both at the local level and outside the region.

b) Encouraging batik business actors to optimize IT facilities.

c) Creating opportunities for investors to invest in the batik center area with a mutually beneficial cooperation model.

d) Increasing batik artisan's access to financing sources through financial institutions, both banking and microfinance.

e) Encouraging income-generating growth for rural communities for other sectors, for example, tourism and trade sectors.

\section{e. Institutional development to support sustainable economic development programs}

a) Strengthening the capacity of multi-stakeholders, especially the bureaucratic level.

b) Development of management of development activities that prioritize efficiency, effectiveness, and accountability of economic development.

c) Building synergy between stakeholders related to batik center development activities.

Tabel 2. SWOT matrix table.

\begin{tabular}{|c|c|c|}
\hline FACTOR & Strength & Weakness \\
\hline External & $\begin{array}{l}\text { - The potential of batik craftsmen is } \\
\text { quite a lot in terms of number and } \\
\text { ability to make batik } \\
\text { - The enthusiasm in the work of the } \\
\text { craftsmen is the main capital in the } \\
\text { development of the batik center } \\
\text { - The experience of batik in the } 3 \\
\text { centers is long enough because } \\
\text { some of the craftsmen have } \\
\text { worked as batik at the Bayat batik } \\
\text { center }\end{array}$ & $\begin{array}{l}\text { - Limited access to relatively large } \\
\text { capital loans, espe- cially for } \\
\text { small entrepre- neurs } \\
\text { - Difficult access and lack of } \\
\text { information related to the ex- } \\
\text { istence of batik centers } \\
\text { - There is a showroom but its } \\
\text { function is not maximized. }\end{array}$ \\
\hline Opportunity & S-O Strategy & W-O Strategy \\
\hline $\begin{array}{l}\text { a. The national and interna- } \\
\text { tional tourism market is } \\
\text { starting to shift from mass } \\
\text { tourism to special interest } \\
\text { tourism, including batik } \\
\text { tourism } \\
\text { b. Regional autonomy pro- vides } \\
\text { an opportunity for lo- cal }\end{array}$ & $\begin{array}{l}\text { a. Development of special interest } \\
\text { tourism potential with the theme } \\
\text { of batik with natural dyes } \\
\text { b. Promotion of batik tourism to } \\
\text { increase the number of visitors to } \\
\text { the batik center } \\
\text { c. Improving the tourist attraction } \\
\text { of batik so as to ensure the length }\end{array}$ & $\begin{array}{l}\text { a. Increase productivity and added } \\
\text { value through skill improvement, } \\
\text { product modification and } \\
\text { design, as well as strengthening } \\
\text { access to market information and } \\
\text { access to capital. } \\
\text { b. Develop and provide a network } \\
\text { of infrastructure that encourages the }\end{array}$ \\
\hline
\end{tabular}




\begin{tabular}{|c|c|c|}
\hline FACTOR & Strength & Weakness \\
\hline $\begin{array}{l}\text { governments to de- velop } \\
\text { their regions, espe- cially } \\
\text { related to the devel- opment } \\
\text { of batik businesses } \\
\text { c. There any positive support } \\
\text { from the Regional } \\
\text { Government of Gunungkidul } \\
\text { Regency for the development } \\
\text { of the batik center. }\end{array}$ & $\begin{array}{l}\text { of stay of tourists is getting } \\
\text { longer. }\end{array}$ & $\begin{array}{l}\text { formation of a synergistic chain of } \\
\text { tourism activities, the economy and } \\
\text { the center of batik production. }\end{array}$ \\
\hline Threat & S-T strategy & W-T Strategy \\
\hline $\begin{array}{l}\text { a. Written batik as the cul- tural } \\
\text { heritage of the In- donesian } \\
\text { nation has been renamed as } \\
\text { the cultural heritage of } \\
\text { other nations }\end{array}$ & $\begin{array}{l}\text { a. Empowering batik centers to } \\
\text { increase batik production and quality } \\
\text { through a system of developing batik } \\
\text { motifs and natural coloring }\end{array}$ & $\begin{array}{l}\text { a. Increasing the managerial } \\
\text { capacity of batik entrepreneurs and } \\
\text { batik craftsmen }\end{array}$ \\
\hline $\begin{array}{l}\text { b. The existence of the AEC } \\
\text { (Asean Economic } \\
\text { Community) makes the } \\
\text { market share more wide } \\
\text { open for foreign products so } \\
\text { that all regen- cies in the } \\
\text { region in Indo- nesia have } \\
\text { batik industries. }\end{array}$ & $\begin{array}{l}\text { b. Encouraging community } \\
\text { participation to be more dominant as } \\
\text { the implementation of the batik } \\
\text { center development program so that } \\
\text { need local community partnership. }\end{array}$ & $\begin{array}{l}\text { b. Assistance to various groups of } \\
\text { batik craftsmen to increase added } \\
\text { value to craftsmen. } \\
\text { c.Encouraging batik business actors } \\
\text { to optimize IT facilities. }\end{array}$ \\
\hline
\end{tabular}

\section{Conclusion}

Based on the internal factor analysis (IFAS) and external factor analysis (EFAS) results, the development of the Batik Industry Center in Gunungkidul Regency already has many strength factors that come from the skills of human resources, namely the presence of a skilled workforce. On the other side they have opportunities that support the development of batik industrial centers with great natural dyes available in the villages of Gunungkidul Regency. However, some weaknesses are owned by the Batik Industry Center in Gunungkidul Regency. Namely, batik artisans have not been able to extract natural dye plants which are the essential ingredients of batik production. They also do not have a Waste Water Treatment Plant. Besides that, there are also limitations in accessing capital.

The results of the analysis of external factors analysis (EFAS) shows that, Gunungkidul Regency has opportunities that support the development of the batik industry center. First, in terms of government, the Special Region of Yogyakarta has the Special Law of Yogyakarta, one of which encourages the cultural development of the batik sector. Second, the Yogyakarta Region as one of the destinations for tourism destinations in Indonesia, both by foreign and domestic tourists, has caused the national and international tourism markets to shift from mass tourism to special interest tourism, including batik tourism. Third, the demand for batik with natural dyes is high, with the emergence of public awareness of a healthy and sustainable environment that is getting better. Fourth, public interest and generations have started to like batik clothing. However, there are threats in the Batik Industry Center in Gunungkidul Regency, namely; 1) The presence of the AEC (ASEAN Economic Community) makes the market share wide open for foreign products, thereby making business opportunities more stringent; 2) almost all districts in Indonesia have a batik industry with the characteristics of each region such as; Solo batik, Pekalongan batik, Madura batik, and so on.

Based on the SWOT analysis, the strategies for developing the Batik Industry Center in 
Gunungkidul Regency include; 1)Development and optimization of batik centers based on the philosophy and characteristics of each center for both natural and synthetic color batik; 2) Improved accessibility and service coverage of transportation, communication, and infrastructure network infrastructure; 3) Human resource development and rural community development; 4) Strengthening financial aspects and access to market information; 5) Institutional development to support sustainable economic development programs. With the implementation of the development strategy of the Batik Industry Center in Gunungkidul Regency, it can encourage the improvement of the welfare of the local village community and make the economy of the rural community in Gunungkidul Regency more developed with the presence of a batik center based on village economic development.

\section{References}

1. S. Rohmah, N. T. Mulatsih, R. W. Bharata, U. G. Kidul, and U. Tidar, "Kontribusi sumber daya manusia dalam meningkatkan sektor industri kreatif untuk keberlanjutan pariwisata di kabupaten gunungkidul," vol. 7, no. 1, pp. 75-88, (2021).

2. S. Haryani and others, "Batik Painting Employees' Welfare In Yogyakarta (An Analysis Of Maqasid Sharia Framework)," Tazkia Islam. Financ. Bus. Rev., vol. 9, no. 2, pp. 128-149, (2016).

3. M. Ahda, D. A. Perwitasari, I. N. Faridah, E. Yuni, and N. Jannah, "Pemahaman pembatik terhadap bahaya bahan kimia dan pewarna di area pembatik Gunungkidul," Semin. Nas. Has. Pengabdi. Kpd. Masy. Univ. Ahmad Dahlan, no. September, pp. 437-442, (2019).

4. B. Wilopo, K. H. TS, and Y. C. Samrotun, "Analisis Penggunaan Informasi Akuntansi Pada Umkm Pengrajin Kayu Batik Desa Wisata Bobung Kabupaten Gunungkidul,” ... dan Sist. Teknol. Inf., vol. 14, no. 3, pp. 458-470, (2019).

5. I. Eny Kustiyah, "Batik Sebagai Identitas Kultural Bangsa Indonesia Di Era Globalisasi,” Gema, vol. 30, no. 52, pp. 2456-2472, (2017).

6. G. Bosworth, "Commercial Counterurbanisation: An Emerging Force in Rural Economic Development," Environ. Plan. A Econ. Sp., vol. 42, no. 4, pp. 966-981, Apr. (2010)

7. Nasfi, "Pengembangan Ekonomi Pedesaan Dalam Rangka Mengentas Kemiskinan di Pedesaan," J. EL-RIYASAH, vol. 11, no. 1, pp. 54-66, (2020).

8. K. A. K. Saputra, P. B. Anggiriawan, A. A. A. E. Trisnadewi, P. G. W. P. Kawisana, and L. G. P. S. Ekajayanti, "Pengelolaan Pendapatan Asli Desa Sebagai Landasan Pembangunan Ekonomi Pedesaan," Ekuitas J. Pendidik. Ekon., vol. 7, no. 1, p. 5, (2019).

9. A. Syahza, "Percepatan Ekonomi Pedesaan Melalui Pembangunan Perkebunan Kelapa Sawit *," J. Ekon. Pembang. Kaji. Masal. Ekon. dan Pembang., vol. 12, no. 2, p. 297, (2011).

10. J. Suh, "Theory and reality of integrated rice-duck farming in Asian developing countries: A systematic review and SWOT analysis," Agric. Syst., vol. 125, pp. 74-81, Mar. (2014).

11. T. Leiber, B. Stensaker, and L. C. Harvey, "Bridging theory and practice of impact evaluation of quality management in higher education institutions: a SWOT analysis," Eur. J. High. Educ., vol. 8, no. 3, pp. 351-365, Jul. (2018)

12. T. Kristanto, E. C. Muliawati, R. Arief, and S. Hidayat, "Strategi peningkatan omset ukm percetakan dengan pendekatan analisis SWOT," Semin. Nas. Sist. Inf. Indones., 
no. November, pp. 258-262, (2017).

13. Ministry of Industry and Commerce, "No Title," (2018).

14. M. A. Benzaghta, A. Elwalda, M. Mousa, I. Erkan, and M. Rahman, "SWOT analysis applications: An integrative literature review," J. Glob. Bus. Insights, vol. 6, no. 1, pp. 55-73, (2021).

15. Y. Wu, "The Marketing Strategies of IKEA in China Using Tools of PESTEL, Five Forces Model and SWOT Analysis," vol. 403, no. Iafsm 2019, pp. 348-355, (2020).

16. N. A. A. Rozmi, A. Nordin, and M. I. A. Bakar, "The Perception of ICT Adoption in Small Medium Enterprise: A SWOT Analysis,” Int. J. Innov. Bus. Strateg., vol. 9, no. 1, pp. 69-79, (2018).

17. D. I. G. Yogyakarta, "Perkembangan Motif Batik Walang Jati Kencono," vol. 3, pp. 111-118, (2020).

18. A. Sardjono, B. A. Prastyo, and D. G. Larasati, "Pelaksanaan Perlindungan Hukum Merek Untuk Pengusaha UKM Batik Di Pekalongan, Solo, Dan Yogyakarta Agus Sardjono, Brian Amy Prastyo, dan Desrezka Gunti Larasati 1," Huk. dan Pembang., vol. 4, p. 21, (2013).

19. H. - AKPAR BSI Yogyakarta, "Analisis Swot Dan Promosi Kerajinan Bambu Desa Wisata Brajan Kabupaten Sleman Yogyakarta,” Khasanah Ilmu, vol. 3, no. 2, (2016).

20. Syauqi Jazul, “Analisis Swot Strategi Pemasaran Produk Pembiayaan Pada Bmt El Syifa Ciganjur Skripsi,” pp. 1-105, (2016).

21. Sri yati prawitasari, "Analisis Swot Sebagai Dasar Perumusan Strategi Pemasaran Berdaya Saing (Studi pada Dealer Honda Tunggul Sakti di Semarang)," Fak. Ekon. Univ. Diponegoro Semarang, p. 75, (2010).

22. H. Kusdarwati, "Ke Sentra Industri Batik Di Lendah.”, (nd). 